\title{
MULTINATIONAL COLLABORATION IN ADVANCED DISTRIBUTED LEARNING
}

\author{
Jannie W. BARRETT
}

\begin{abstract}
dvanced Distributed Learning (ADL) has bridged the international training gap that existed in the past, enabling students from around the world to access courses, communicate with other students, share information, and interact with instructors, all in real-time.
\end{abstract}

\section{Why ADL?}

Among the advantages ADL provides are:

- Cost Savings;

- Increased Productivity;

- 24/7 Accessibility;

- Global Distribution;

- Tailored Learning;

- References;

- Promotion of collaborative learning.

Cost associated with training typically includes time, travel, lodging, meals and incidentals, registration fees, and tuition. Cost associated with traditional distance learning includes bulk mailings, manual tracking, and cumbersome updates and remailings. With ADL, the only cost association is time.

ADL also results in increased productivity. The need to leave the workplace in order to gain access to training is eliminated; an individual can morph the training into their current schedule. With seven days per week, twenty-four hours per day (24/7) Internet access, a user can access the internet-based ADL courses at anytime, from anywhere.

ADL provides the ability to reach geographically dispersed populations with a uniform and consistent approach. Course materials can be consistently updated, and 
updates are immediate. Users discuss, debate, and brainstorm with instructors and colleagues around the globe. Individual customized learning environments adapt to each user's style of learning, with self-paced study and the automated progress tracking process.

\section{Background}

As part of the NATO Summit communiqué, ${ }^{1}$ on 25 April 1999, the heads of state and governments of forty-two participating member nations endorsed the Partnership for Peace (PfP) education and training concept, including the implementation of the PfP Consortium of Defense Academies and Security Studies Institutes.

The United States and Switzerland determined that the establishment of an opensource, web-based environment linking the PfP Consortium in a collaborative network that facilitates the development of ADL was critical to the Consortium's success. To this end, the two countries signed a Memorandum of Understanding (MoU) on 25 April 1999, designed to establish an orderly framework, policies, procedures, and the respective responsibilities of the participants regarding mutual support in the development of this web-based environment. At the June 1998 EuroAtlantic Partnership Council (EAPC) Ministerial the then Defense Secretary Cohen stated that "The United States has a three-part proposal for building among nations this enhanced education and training framework..." That proposal included a cooperative network of PfP training centers, PfP Simulation Network, and PfP Consortium of Defense Academies and Security Studies Institutes. The intent includes the enhancement of interoperability and regional security and the improvement of education and training.

A Joint Planning Document (JPD) was developed and published to implement the MoU. This document, formally approved during a formal signing ceremony at the Pentagon on 13 May 2002, provides guidance to achieve the vision and strategic, collaborative, educational, and technological goals of the MoU, thereby initiating the multinational collaboration efforts for ADL. These efforts to date have resulted in numerous contributions to security cooperation. ADL products have been used in Swedish led exercises, the NATO Defense College, NATO School, and numerous other organizations throughout Europe.

\section{Roles and Responsibilities}

The responsibilities of the Swiss - U.S. MoU participants are carried out through a hierarchy of Designated Agents, Implementing Agents, and Academic Advisory Support Elements whose work is coordinated through a Joint Planning Committee (JPC). The Designated Agents are responsible for the implementation of the MoU. 
The United States Joint Forces Command (USJFCOM) is the Designated Agent for the United States. The General Secretariat of the Federal Department of Defense, Civil Protection, and Sports is the Designated Agent for Switzerland. The Implementing Agents assist the Designated Agents in carrying out the provisions of the MoU.

The Academic Advisory Support Elements carry out the academic provisions of the MoU. The Joint Planning Committee, co-chaired by representatives of the Designated Agents, is composed of representatives from the Implementing Agents and the Academic Advisory Support Elements. It meets as required to address all matters relevant to the project (oversight, policy, planning, execution).

In January 2000, a U.S. Cooperative Development Team (CDT), consisting of a Team Leader/Planner, an Instructional Systems Designer/Training Developer, and a Systems Engineer, was formed to facilitate the conversion of traditional learning material to standards-based, internet-enabled interactive courseware. In February 2001, a similar Swiss CDT was formed to help support the ever-increasing demand for content/course conversions. Since that time, Canadian, Ukrainian, Russian, Bulgarian, Turkish, Swedish, Finnish, and Belgian CDTs have been formed and trained by the U.S. CDT. Additionally, the U.S. and Switzerland each provide Technical Program Integrators (TPIs) responsible for the coordination of all technical integration efforts of the project.

While the original CDTs were forming, and beginning to develop the first courses, a group of system engineers and programmers representing many PfP countries, including, Lithuania, Bulgaria, Switzerland, Germany, Estonia, Belgium, and the Republic of Georgia formed as the ADL LMS Developer's Group to design and develop the PfP Learning Management System (PfP LMS). The PfP LMS was tailored and customized to the learning environment needs of its targeted users, instructors, and developers. An ADL LMS working group was formed to provide user's input into the development and refinement of the PfP LMS. Unlike commercial learning management systems, the PfP LMS is a completely free and open-source system. Since the release of the first prototype, the PfP LMS has been deployed to other NATO and PfP Consortium organizations, where it is actively in use today. Two prototypes have been released, and a new Sharable Content Object Reference Model (SCORM) conformant version is expected to be released in 2004.

The important contributions of the CDTs in developing and converting traditional learning material into media rich, internet-enabled interactive courseware cannot be overstated. Additionally, new international CDTs continue to be formed and trained. 


\section{Milestones}

The success of the Swiss and U.S. - MoU efforts are well documented, and the demand for quality products and services provided by the CDTs has quickly grown beyond PfP to NATO and others.

A good example of multinational collaboration in ADL is demonstrated in the George C. Marshall European Center (GCMC) for Security Studies course, 'Introduction to Human Rights.' It is a good example of how an instructor in a geographically separate location (Australia) can successfully administer a course to students throughout Europe using the interactive capabilities of the PfP LMS.

Another course, English Skills for Staff Officers 2 (ESSO 2), recently created by the Ukrainian CDT, is used to engage officers in language learning and to facilitate the language learning process by the use of modern technologies. ${ }^{2}$ The course is primarily intended for self-study and is expected to be used by military officers to prepare for classroom training sessions, as an instrument to help keep language skills current, and as a reference book containing templates, examples and guidelines for applying English writing and speaking skills.

Recognizing and leveraging off the success of the Swiss - U.S. MoU, NATO requested the establishment and execution of a NATO/PfP ADL Programme prototype to determine if NATO might benefit from ADL. The primary course in that prototype was the Introduction to NATO course.

In January of 2001, multinational collaboration in ADL was demonstrated when CDTs from Canada, Switzerland, and the U.S. began collaborations with four Subject Matter Experts (SMEs) from NATO Defense College (NDC), the United States National Defense University (NDU), the NATO School, and Headquarters, and the NATO Office of Information and Press. The course, typically given by NDC to NATO and PfP officers, was intended to teach the basics about NATO prior to the officers' enrollment at the school. The Introduction to NATO course is an introductory online course, primarily used to level the playing field for in-coming NATO students. Additionally, it is used as a NATO refresher for students after departure, and as a NATO introduction for individuals assigned to NATO, but unable to attend an onsite course. It is an excellent example of international cooperation and collaboration. In 2003, the course was updated, and expanded from five to nine modules, and is currently being translated into Russian by the Russian CDT.

Feedback analysis from a test-bed of approximately 400 NATO members revealed that over 90 percent of them rated the original Introduction to NATO course as either useful or very useful. In March of 2003, Allied Command Transformation (ACT) prepared and presented a NATO/PfP ADL Programme Evaluation Report to the 
NATO Military Committee. Based on the success of the Introduction to NATO ADL prototype, direction was given to develop NATO/PfP ADL initial operational capability.

\section{PfP LMS Course Access}

To date, more than twenty courses have been developed in the PfP LMS and are available to a multinational audience. Completed courses currently in the PfP LMS include:

\begin{tabular}{|l|l|}
\hline English Skills for Staff Officers 2 & Conflict Management and Negotiation \\
\hline $\begin{array}{l}\text { Bulgaria in South Eastern Europe } \\
\text { Politics, Security, Economy }\end{array}$ & $\begin{array}{l}\text { Overview of the Inter-American System } \\
\text { (English, Spanish, and Portuguese } \\
\text { versions) }\end{array}$ \\
\hline Ethnic Conflict and Peace Operations & $\begin{array}{l}\text { Combined Joint Task Force training } \\
\text { Modules }\end{array}$ \\
\hline $\begin{array}{l}\text { Terrorism and Its Implications for } \\
\text { Democratic States }\end{array}$ & $\begin{array}{l}\text { Combating Terrorism and Illegal } \\
\text { Trafficking }\end{array}$ \\
\hline $\begin{array}{l}\text { SPIRIT: Security, International Relations, } \\
\text { and Information Technology }\end{array}$ & $\begin{array}{l}\text { Peace Support Operations Staff Officer } \\
\text { Orientation Course }\end{array}$ \\
\hline Introduction to Human Rights & NATO Standardization Module \\
\hline $\begin{array}{l}\text { Introduction to International } \\
\text { Humanitarian Law }\end{array}$ & Civil Military Cooperation in NATO \\
\hline $\begin{array}{l}\text { Introduction to Microsoft Office } \\
\text { Applications }\end{array}$ & PfP Programme Module \\
\hline Introduction to NATO & Civil Emergency Planning Module \\
\hline $\begin{array}{l}\text { Bulgarian Participation in Peace Support } \\
\text { Operations }\end{array}$ & $\begin{array}{l}\text { NATO Modelling and Simulation } \\
\text { Orientation }\end{array}$ \\
\hline International Security Risks & Conducting a Computer Assisted Exercise \\
\hline
\end{tabular}

Currently, over twenty additional courses are scheduled, proposed, or in various stages of completion.

While there are several websites from which various courses may be accessed, one of the more comprehensive sites is the NATO PfP Advanced Distributed Learning Website. ${ }^{3}$ Selecting a course title will link to an instance of the PfP LMS, wherein a first-time user must register, thereby establishing a Username and Password. While each LMS instance requires a separate registration, only restricted or limited access courses require a waiting period for password assignment. Upon accessing the PfP LMS courses, online guides are available as well as course specific instructions. 


\section{Vision}

The Vision for the future expanded implementation of the Swiss - U.S. MoU (20012006) is to create, operate, and maintain an open source, standards based system, providing multi-sensory, universal access to a knowledge portal in support of international security cooperation.

To that end, plans have been developed to include strategic, collaborative, educational, and technological goals. These strategies will foster reusable, modular, quality content that responds to user defined information and learning requirements. To meet these goals and requirements, the Consortium, industry, government, educational and other sources will be leveraged to incorporate leading edge technologies.

The way ahead includes development of the next (SCORM conformant) version of the PfP LMS, continued course conversions to web-based instruction, and the implementation of the "Vision" for the future of the program. All efforts are intended to enhance the work of the Consortium and to benefit other willing participants.

\section{Notes:}

1 An Alliance for the 21st Century, NATO Summit communiqué (Washington, D.C.: Issued by the Heads of State and Government participating in the meeting of the North Atlantic Council, 24 April 1999), <http://www.nato.int/docu/pr/1999/p99-064e.htm> (4 May 2004).

2 The ESSO development is described in detail in the accompanying article: Olga Danylova, Peggy Garza, Bonnie Mihalka, Kateryna Synytsya, and Olexiy Voychenko, "English Skills for Staff Officers: Collaborative Development of the Distance Course," Information \& Security: An International Journal 14 (2004): 32-44.

The reader may refer to the "ADL Course Archives" section at https://adl.act.nato.int.

JANNIE W. BARRETT is Team Leader for the Regional Security Cooperation Network's Partnership for Peace Cooperative Development Team at the United States Joint Forces Command's Joint Warfighting Center. She holds a Master's Degree in Education from Hampton University, and an undergraduate degree from North Carolina Central University. In addition to specializing for many years in the field of education as an Instructor in corporate education development and as an Instructional Systems Developer, she is also a pioneer of the U.S. - Swiss MOU's Advanced Distributed Learning Project and a major contributor to the design and development of several courses within the PfP Learning Management System. Having briefed many international audiences on the advantages of ADL and continually training new CDT members to design and develop training, she is at the leading edge of advances in ADL. For correspondence: Jannie W. Barrett, Regional Security Cooperation Network/PfP CDT Leader, United States Joint Forces Command, Joint Warfighting Center (JWFC), 116 Lakeview Parkway, Suffolk, VA 23435-2697. E-mail: Jannie.Barrett@jfcom.mil. 